\title{
Examining the Pre- and Post-Competition State Anxiety Levels of Sportswomen of the Dutch Women's Volleyball National Team
}

\author{
Mustafa Önder Şekeroğlu \\ Correspondence: Mustafa Önder Şekeroğlu, High School of Physical Education and Sports, Muş Alparslan University, \\ MUŞ, Turkey.
}

Received: November 26, 2017

Accepted: December 27, 2017

Online Published: December 28, 2017

doi:10.11114/jets.v5i13.2898

URL: https://doi.org/10.11114/jets.v5i13.2898

\begin{abstract}
This study was planned and conducted in order to examine the pre- and post-competition state anxiety levels of sportswomen of the Dutch women's volleyball national team. This descriptive study aimed at identifying the pre- and post-competition state anxiety levels of sportswomen of the Dutch women's volleyball national team is in the general survey model. The "Competitive State Anxiety Inventory-2" (CSAI-2) consisting of 27 questions, developed by Martens, Burton, Vealey, Bump and Smith (1990) was applied to the 14 sportswomen voluntarily participating in the study. The anxiety inventory comprises the cognitive, somatic and self-confidence sub-factors. Each factor consists of 9 items. The Cronbach Alpha Internal Consistency coefficient was found as 0.91 in Cognitive Anxiety, 0.62 in Physical Anxiety, and 0.95 in Self-Confidence. According to the study conducted, comparing the pre- and post-competition anxiety levels of the sportswomen of the women's national volleyball team, a significant difference was found in cognitive anxiety, somatic anxiety and self- confidence anxiety levels of $p<0,05$. In anxiety levels according to years of practicing sports, a significant difference at a level of $\mathrm{p}<0,05$ was found in pre-competitive somatic anxiety.
\end{abstract}

Keywords: volleyball, anxiety, sportsperson, competition

\section{Introduction}

Humans have a highly complex structure, which is rendered even more complex with the fact that their needs have biological, psychological and social qualities. Human beings' biological determinants, their rich psychological world, and their personality within their web of social relationships are among the most important factors in understanding the human being. Research on human behaviour must consider dynamic determinants. In assessing behaviour, the individual's psychological world and psychological determinants must be considered (İlbay, 2000).

One of the basic emotions in psychology is anxiety. Anxiety is a phenomenon concerning excitement that generally occurs under threating conditions. It is an emotional state that can be felt both emotionally and physically, the consequences of which can be observed in behaviour. Anxiety is an oppressing condition of expectation regarding the future, which is manifested through physical, emotional and mental changes experienced by one who is faced with a stimulus (Tol, 1995; Akandere, 2000; Kapıkıran, 2002; Tekindal, 2010).

Anxiety is considered and examined under two headings, namely state and trait. While trait anxiety stems from the individual's personality, state anxiety is the expectation of a negative result felt by an individual when faced with a specific situation. At the same time it is an emotional status that causes an increase in apprehension, fear, tension and psychological stimulation. Therefore its intensity and fluctuation differs, and gradually has an effect on the individual. State anxiety must be differentiated from trait anxiety, which is a personality trait, and which depends on individual differences in intensity with time. Anxiety consists of three basic elements which are independent of each other while also being in interaction. These are somatic (emotionality), cognitive (apprehension) and behavioural changes. The interrelation between the behavioural components of anxiety and performance is not clear. It is indicated that while cognitive anxiety has a negative effect on sports performance, somatic anxiety tends to harm motor skills at a secondary degree (Spielberger, 1972; Polman et al., 2007; Zeng et al., 2008).

It has been shown that sports performance and success is not connected only with biomechanical factors, but is also affected by psychological factors. One of these factors is the anxiety experienced by the sportsperson, which has a negative effect on sportspeople during competitions. Before the competition, sportspeople enter a state of anxiety, fear 
and excitement, and reflect this state in their physiological, mental, emotional and social reactions. Many sportspeople may have a stomachache or negative thoughts before a competition, or may exhibit aggressive behaviour, reflecting this to their environment. Therefore, how great the effects of stress and anxiety are on sportspeople before important competitions can be easily observed. For instance, in volleyball, missed passes, lack of coordination, and timing errors occur more frequently in times of anxiety. Many teams and sportspeople wish to learn the elements of psychological preparation in order to increase performance and facilitate success (Jones, 1990; Tol, 1995; Konter, 1996; Erbaş, 2000).

This study aims at examining the pre- and post-competition state anxiety levels that affect the sports performance and success of sportspeople.

\section{Method}

\subsection{Model of the Study}

This descriptive study aimed at identifying the pre- and post-competition state anxiety levels of sportswomen of the Dutch women's volleyball national team is in the general survey model.

\subsection{Study Group}

This study was conducted using an anxiety scale that was applied to the Dutch national team sportswomen during the 2016 Rio Olympic Games European Continent Eliminations that were held between 4-9 January 2016 at the Ankara Başkent Gymnasium. The permission necessary to apply the scale was obtained from the national team technical team. 14 sportswomen volunteered to participate in the study. Afterwards, the sportswomen were informed, and the questionnaire was applied before and after the competition.

\subsection{The Scale, Reliability and Factor Analyses Employed in the Study}

The "Competitive State Anxiety Inventory-2" (CSAI-2) consisting of 27 questions, developed by Martens, Burton, Vealey, Bump and Smith (1990) was used in the study. The anxiety inventory comprises the cognitive, somatic and self-confidence sub-factors. Each factor consists of 9 items (Martens 1990).

Table 1. The Crobach's Alpha Coefficients of Anxiety Levels

\begin{tabular}{ll}
\hline & Crombach's Alpha \\
\hline Cognitive Anxiety & $-0,917$ \\
Somatic Anxiety & $-0,624$ \\
Self-confidence & $-0,956$ \\
\hline
\end{tabular}

The Cronbach Alpha Internal Consistency coefficient was found as 0.91 in Cognitive Anxiety, 0.62 in Physical Anxiety, and 0.95 in Self-Confidence.

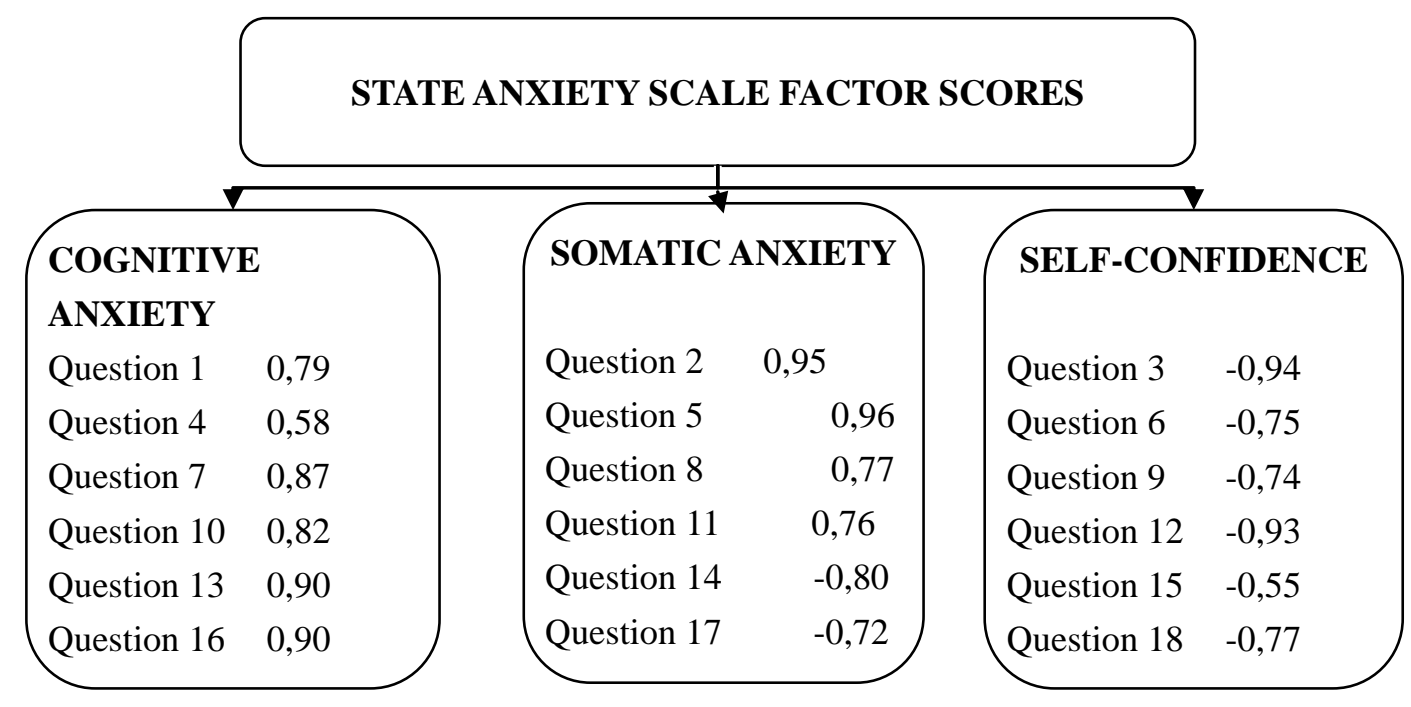

Figure 1. Sub-factor Analyses of the State Anxiety Scale

\section{Analysis of the Data}

The SPSS 23 package software was used in evaluating the data obtained. Frequency and percent analysis were used in identifying socio-demographic properties. The independent-t test method was used in comparing the sportswomen's preand post-competition anxiety levels. The One-way analysis of variance Anova was used in evaluating the anxiety levels 
in relation to sportswomen's ages. Also, a reliability analysis and factor analyses were conducted. Some tables were provided in graphs in the findings section.

\section{Findings}

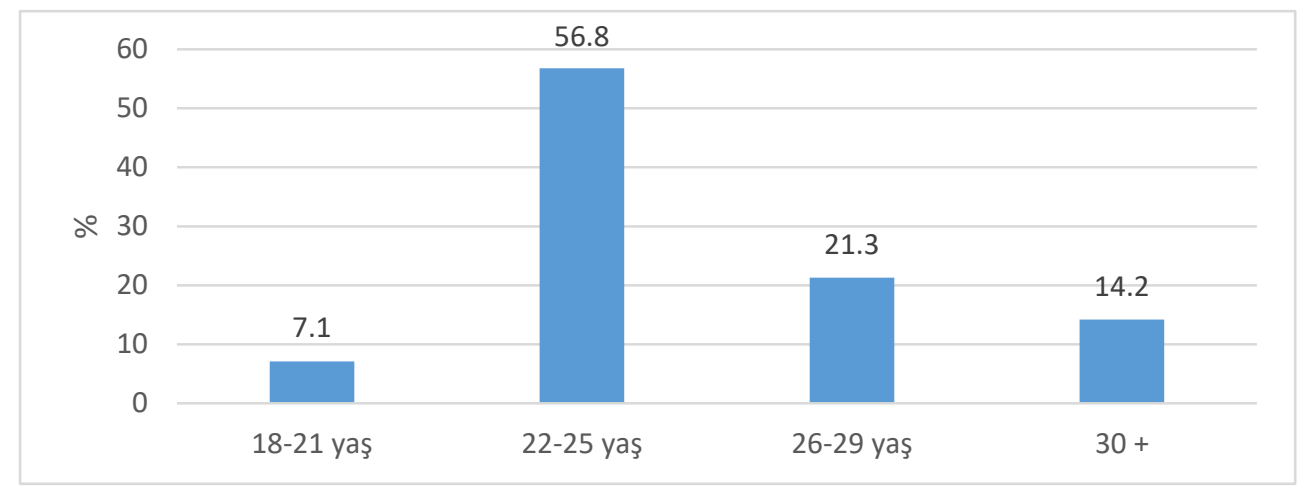

Graph 1. Age Distribution of Participants

An examination of the graph revealed the fact that $7,1 \%$ of the volleyball players were between the ages $18-21,56,8 \%$ were between $22-25,21,3 \%$ between $26-29$, and $14,2 \%$ were between 30 and over.

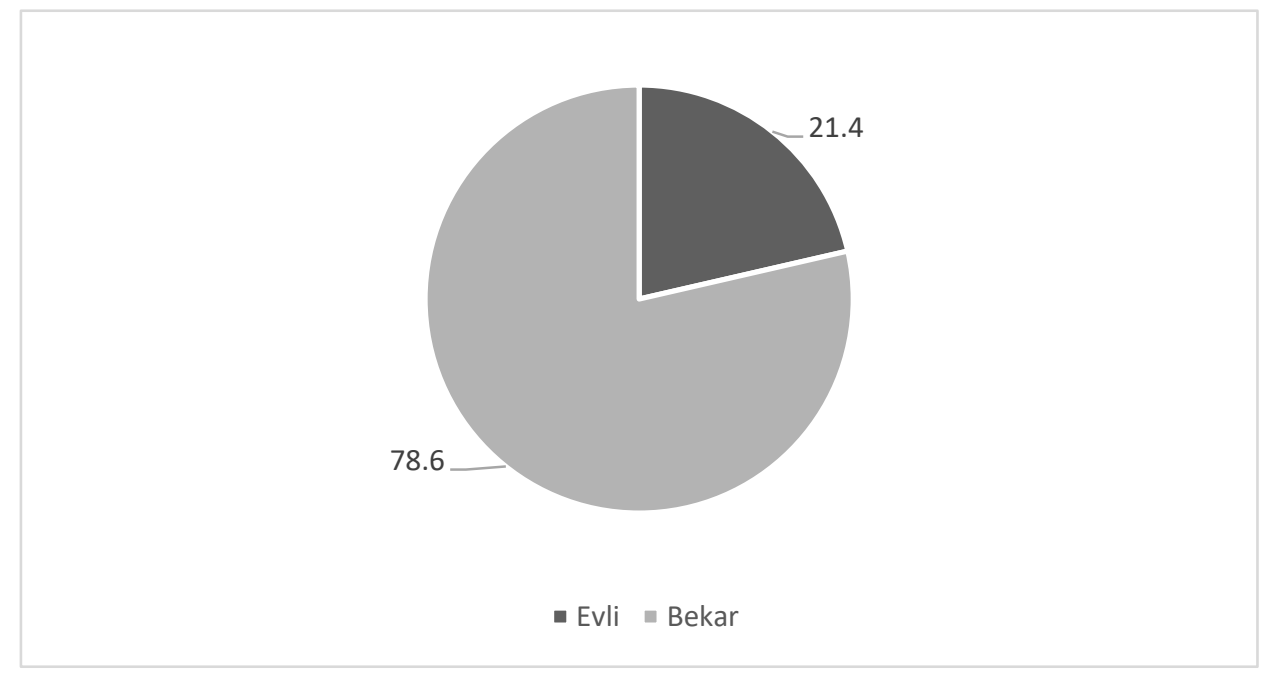

Graph 2. Marital status of participants

According to the research, $\% 78,6$ of the volleyball players were single, while $21,4 \%$ were married.

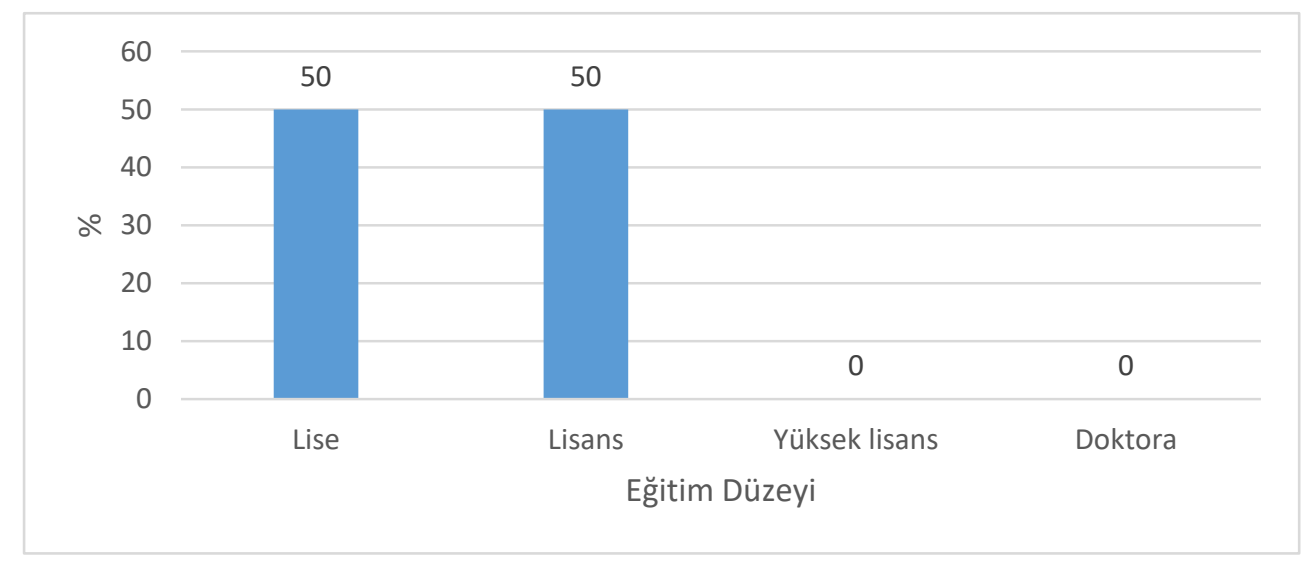

Graph 3. Educational Status of Participants

When the volleyball players' educational status was examined, it was found that $50 \%$ were high school graduates while $50 \%$ were university graduates. None of them had master's or doctorate degrees. 
Table 2. Age of starting sports of participants

\begin{tabular}{lll}
\hline & F & $\%$ \\
\hline 4-6 ages & 1 & 7,1 \\
7-9 ages & 7 & 50,0 \\
10-12 ages & 6 & 42,9 \\
Total & 14 & 100,0 \\
\hline
\end{tabular}

According to the table examining the sportswomen's ages of starting sports, it was found that $7,1 \%$ started between $4-6$ ages, 50\% between 7-9 ages and 42,9 between 10-12 ages.

Table 3. Participants' Year in Sports

\begin{tabular}{lcr}
\hline & F & \% \\
\hline 7-9 years & 9 & 64,3 \\
9-11 years & 3 & 21,4 \\
12+ years & 2 & 14,3 \\
Total & 14 & 100,0
\end{tabular}

An examination of the sportswomen's years in sports revealed that $64,3 \%$ had been occupied in sports between $7-9$ years, $21,4 \%$ between $9-11$ years and $14,3 \%$ for 12 and more.

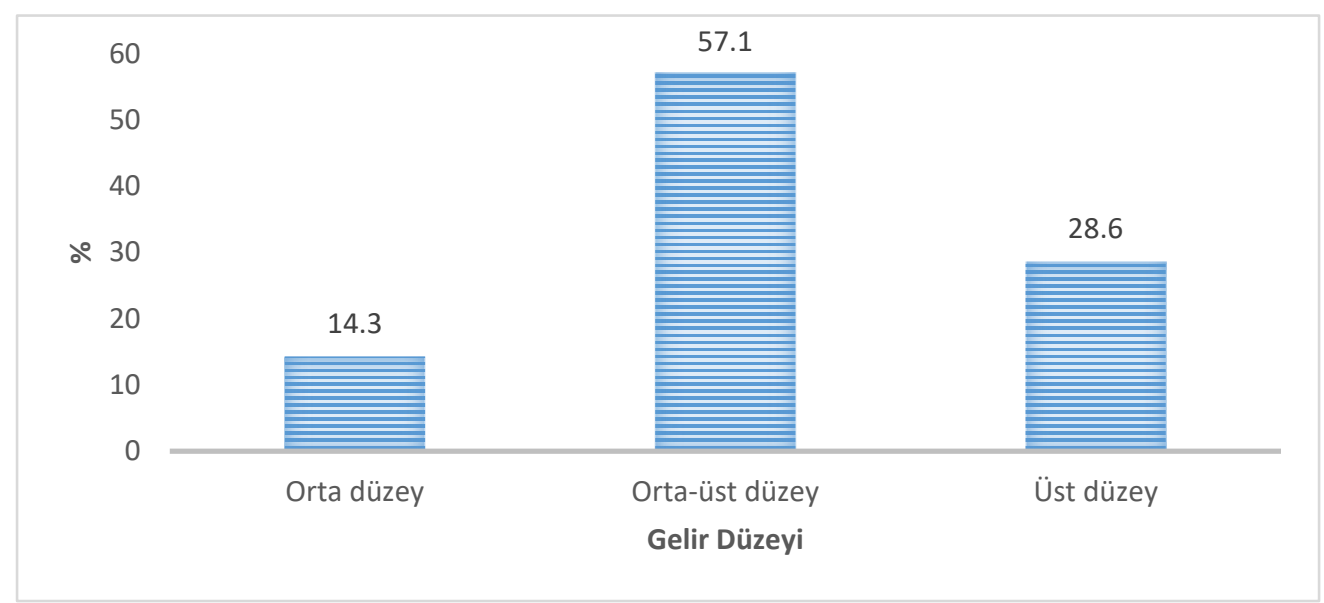

Graph 4. Income Status of Participants

According to the graph, $14,3 \%$ of the sportswomen belonged to a medium income level, $57,1 \%$ to an upper-middle income level, and $28,6 \%$ to an upper income level.

Table 4. Examination of the Pre- and Post-Competition Anxiety Levels of the Participants

\begin{tabular}{llllrc}
\hline & Group & Average & Standard Deviation & $\mathrm{T}$ & $\mathrm{p}$ \\
\hline Cognitive & Pre-competition & 2,16 & 0,14 & 4,65 & $<0,001$ \\
Anxiety & Post-competition & 1,38 & 0,61 & & \\
\multirow{2}{*}{ Somatic Anxiety } & Pre-competition & 2,11 & 0,22 & 3,36 & $<0,01$ \\
& Post-competition & 1,82 & 0,23 & & \\
Self-confidence & Pre-competition & 2,41 & 0,21 & $-4,40$ & $<0,001$ \\
& Post-competition & 3,41 & 0,81 & & \\
\hline
\end{tabular}

According to the study, a comparison of the sportswomen's pre- and post-competition anxiety levels produced statistically significant differences of $\mathrm{p}<0,001$ in cognitive anxiety, of $\mathrm{p}<0,01$ in somatic anxiety, and of $\mathrm{p}<0,001$ in self-confidence. 


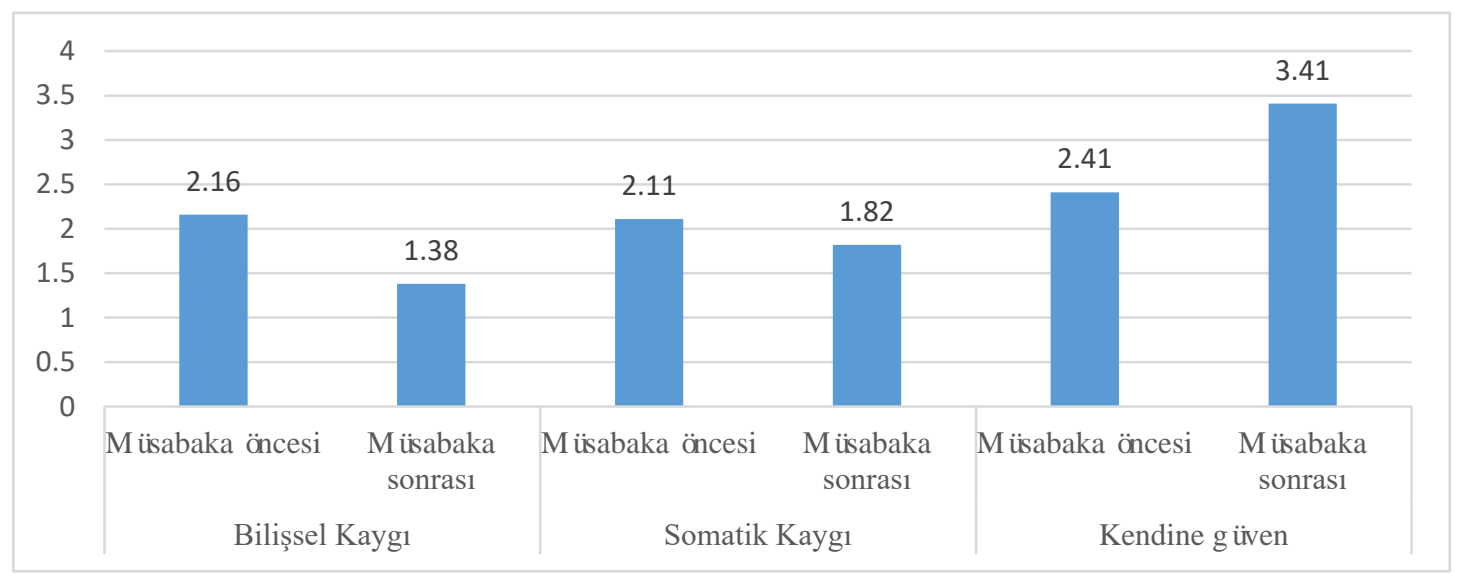

Graph 5. Average of the Pre- and Post-Competition Anxiety Levels of the Participants

According to the graph, the cognitive and somatic anxiety scores that were high before the competition dropped after the competition, while the low point before the competition rose after the competition.

Table 5. Examination of Pre-Competition State Anxiety Level According to Years in Sports

\begin{tabular}{llccccc}
\hline & N & Average & $\begin{array}{c}\text { Standard } \\
\text { Deviation }\end{array}$ & $\mathrm{f}$ & $\mathrm{p}$ \\
\hline \multirow{3}{*}{ Cognitive Anxiety } & 7-9 years & 9 & 2,17 & 0,14 &, 147 & $>0,05$ \\
& 9-11 years & 3 & 2,18 & 0,23 & & \\
& 12+ years & 2 & 2,11 & 0,00 & & \\
Somatic Anxiety & 7-9 years & 9 & 2,04 & 0,09 & 5,326 & \\
& 9-11 years & 3 & 2,40 & 0,35 & & \\
& 12+ years & 2 & 2,00 & 0,00 & & \\
Self-confidence & 7-9 years & 9 & 2,41 & 0,22 & & \\
& 9-11 years & 3 & 2,29 & 0,23 & & \\
\hline
\end{tabular}

According to the Anova test, a statistically significant difference was not found in pre-competition cognitive and self-confidence anxiety levels. A statistically significant difference at the level of $p<0,05$, however, was found in somatic anxiety.

According to the Tukey Hsd test that was conducted, the difference occurring in somatic anxiety was found to stem from the 7-9 and 9-11 years in sports.

Table 6. Examination of the Participants' Post-Competition State Anxiety Levels According to Years in Sports

\begin{tabular}{|c|c|c|c|c|c|c|}
\hline & & $\mathrm{N}$ & Average & $\begin{array}{c}\text { Standard } \\
\text { Deviation }\end{array}$ & $\mathrm{F}$ & $\mathrm{P}$ \\
\hline \multirow{3}{*}{ Cognitive Anxiety } & $7-9$ years & 9 & 1,27 & 0,54 & & \\
\hline & $9-11$ years & 3 & 1,92 & 0,81 & 1,693 & $>0,05$ \\
\hline & $12+$ years & 2 & 1,11 & 0,15 & & \\
\hline \multirow{3}{*}{ Somatic Anxiety } & $7-9$ years & 9 & 1,82 & 0,24 & ,680 & $>0,05$ \\
\hline & $9-11$ years & 3 & 1,92 & 0,27 & & \\
\hline & $12+$ years & 2 & 1,66 & 0,00 & & \\
\hline \multirow{3}{*}{ Self-confidence } & $7-9$ years & 9 & 3,51 & 0,74 & 1,408 & $>0,05$ \\
\hline & $9-11$ years & 3 & 2,77 & 1,09 & & \\
\hline & $12+$ years & 2 & 3,88 & 0,00 & & \\
\hline
\end{tabular}

As seen in Table 6, in the anova test a statistical difference at the level of $>0,05$ was not found in cognitive, somatic and self-confidence anxiety levels after the competition.

\section{Discussion and Conclusion}

Anxiety is manifested in both physical and somatic, and mental ways. This occurs when sitting an exam, delivering a speech, undergoing an interview for a job application, or participating in the most important athletic competition to date, in other words, when we are worried about something (Özbay 2012).

During a research conducted by Orlick and Partington on 235 Canadian Olympic sportspeople, the sportspeople participating in the Olympic games evaluated the three major preparedness factors, namely the mental, physical and 
technical factors. Sportspeople that succeeded in making it to the finals considered the mental preparedness factor very important. The statistical results revealed a significant correlation between getting to the finals and the importance given to mental preparedness (Jones 1990).

According to Weinberger, many sportspeople in the Olympic games and championship games, although physically and technically prepared, fail to release this potential under stressful conditions. This situation is not specific to Olympic and international sportspeople. In all competitive activities, the stress levels and mental preparedness of sportspeople from the lowest to the highest level prove important in their success (Weinberger 1989).

Huband and McKelvie (1986) report that the state anxiety of sportspeople increase before the competition, and that the state anxiety of sportspeople with a higher trait anxiety is higher during competitions compared to those with low trait anxiety levels.

Başoğlu and Şekeroğlu (2016) examined the state anxiety levels of sportswomen from the Turkish women's volleyball national team, finding a significant difference in cognitive anxiety levels between pre- and post-competition anxiety levels.

According to another study, the state anxiety levels of sportspeople from the youth national team increased 1 day before the competition, continued to increase up to 2 hours before, and then demonstrated a slight drop 30 minutes before the competition. However, no significant difference was found between these sportspeople's state anxiety levels. In the state anxiety levels of star national team sportspeople, however, a continuous increase was observed up to 1 hour before the competition, which was followed by a drop 30 minutes before the competition. Changes in the state anxiety of the sportspeople of both teams appear to be similar, however the state anxiety levels of the star national team sportspeople demonstrated a higher increase. Also, a significant difference was found between the state anxiety scores of these sportspeople (Çağlar 2014).

The study conducted by Özbay (2012) found a statistically significant difference between the pre- and post-competition anxiety levels of wrestlers.

Another study conducted by Martens, Vealey and Burton (1990) on gymnasts found an increase in somatic state anxiety from 1 day before up to 2 hours before the competition, which demonstrated a slight decrease just before the competition. If the increase in state anxiety in this study was to be considered as stemming from the somatic component of state anxiety, the findings of Martens and colleagues would be considered to support the findings of this study. Similar to these findings, many studies showed that somatic state anxiety increased as the competition drew closer (Jones 1989; Jones et al., 1991; Karteroliotis 1987; Martens et al., 1990).

In a study conducted by Yücel (2003) on taekwondo sportspeople, the high or low levels of state and trait anxiety in these sportspeople were found to be unrelated to the subjects' ages.

In conclusion, differences were found in the cognitive anxiety, somatic anxiety and self-confidence levels of the sportswomen before and after competitions. For this reason, trainers must consider the sportsperson's physiological and psychological traits, study their social environment carefully, and develop approaches that would decrease anxiety. Programmes to teach sportspeople techniques and methods to cope with anxiety must be applied, to which end specialists and psychologists must be employed in clubs.

\section{References}

Akandere, M. (2000). Kaygı ile Başa Çıkmada Sporun Etkisinin Kardeş Sayısı Açısından incelenmesi. Atatürk Üniversitesi Beden Eğitimi ve Spor Okulu 1. Spor Kongresi

Başoğlu, B., \& Şekeroğlu, M. Ö. (2016). Türkiye Kadınlar Voleybol Milli Takım Sporcularının Müsabaka Öncesi Ve Sonrası Durumluk Kaygı Düzeylerinin İncelenmesi. Akademik Sosyal Araştırmalar Dergisi, 25, 303-312.

Çağlar, E. (2014). Genç ve Yıldız Hentbol Milli Takımında Bulunan Erkek Sporcuların Kaygı Düzeylerinin Zaman İçindeki Değişimleri. CBÜ Beden Eğitimi ve Spor Bilimleri Dergisi, 3(3).

Erbaş, M. (2000). Türkiye Basketbol II. Ligindeki Oyuncuların Bazı Kişisel Değişkenlerinin Durumluk Kaygı Üzerine Etkileri ve Durumluk Kaygının Takım İçi ilişkilerine Etkisinin Araştırılması. Yüksek Lisans Tezi. Trakya Üniversitesi, Edirne.

Huband, E. D., \& McKelvie, S. J. (1986). Pre And Post Game State Anxiety İn Team Athletes High And Low İn Competitive Trait Anxiety. International Journal Of Sport Psychology, 17, 191-198.

İlbay, A. B. (2000). Bireylerin Anksiyete, Empatik Beceri ve İlişkili, Özerklik Düzeylerinin Karşılaştırılması. Yüksek Lisans Tezi. Atatürk Üniversitesi, Erzurum.

Jones, G., \& Hardly, L. (1990). The Acamedic Study Of Stress İn Sport, Stress And Performans İn Sport, John Wiley 
And Sons, Chichester.

Jones, G., Swain, A., \& Cale, A. (1991). Gender Differences in Precompetition Temporal Patterning and Antecedents of Anxiety and Self-Confidence. Journal of Sport \& Exercise Psychology, 13(1). https://doi.org/10.1123/jsep.13.1.1

Jones, J. G., \& Cale, A. (1989). Relationships Between Multidimensional Competitive State Anxiety And Cognitive And Motor Subcomponents Of Performance. Journal Of Sports Sciences, 7(3), 229-240. https://doi.org/10.1080/02640418908729843

Kapıkıran, Ş. (2002). Üniversite Öğrencilerinin Sınav Kaygısının Bazı Psiko-Sosyal Değişkenlerle İlişkisi Üzerine Bir İnceleme. Pamukkale Üniversitesi Eğitim Fakültesi Dergisi, 11, 34-43.

Karteroliotis, C., \& Gill, D. L. (1987). Temporal Changes in Psychological and Physiological Components of State Anxiety . Journal of Sport Psychology, 9, 261-274. https://doi.org/10.1123/jsp.9.3.261

Konter, E. (1996). Profesyonel Futbolcuların Bazı Kişisel Değişkenlerinin Durumluk Kaygı Üzerine Etkileri ve Durumluk Kaygının Takım îçi İlişkilerine Etkisinin Araştırılması. Yüksek Lisans Tezi. Çukurova Üniversitesi, Adana

Martens, R., Burton, D., Vealey, R., Bump, L., \& Smith, D. (1990). Development and validation of the Competitive State Anxiety Inventory-2 (CSAI-2. Competitive anxiety in sport IL: Human Kinetics, 117-213.

Özbay, S. (2012). Büyükler Güreş Milli Takımında Yer Alan Sporcuların, Müsabaka Öncesi Ve Sonrası Durumluk Kaygı Düzeylerinin Karşılaştırılması, Yüksek Lisans Tezi. Karamaoğlu Mehmet Bey Üniversitesi, Karaman.

Polman, R., Rowcliffe, N., Borkoles, E., \& Levy, A. (2007). Precompetitive State Anxiety Objective And Subjective Performance And Causal Attributions İn Competitive Swimmers, Pediatric Exercise Science Feb; 19(1), 39-50.

Spielberger, C. D. (1972). Conceptual and Methodological Issues in Anxiety Research. Anxiety: Current Trends in Theory and Research. Academic Press, 481-493. https://doi.org/10.1016/B978-0-12-657402-9.50013-2

Tekindal, M. (2010). İlköğretim Okullarındaki Öğrencilerin Sürekli Kaygı Düzeylerinin Çeşitli Değişkenlere Göre İncelenmesi. Gazi Üniversitesi Endüstriyel Sanatlar Ĕ̈itim Fakültesi Dergisi, 26, 79-93.

Tol, A. (1995). Kaygının Performansa Etkisi. Yüksek Lisans Tezi, Selçuk Üniversitesi, Konya.

Weinberger, R. (1989). Anxiety, Arousal And Motor Performans: Theory, Research And Applications. Hackford D., Spielberger C., Anxiety İn Sport An İnternational Perspective, Hemisphere Publishing Corpotation, Newyork, 97-110.

Yücel, E. O. (2003). Taekwondocuların Durumluk ve Sürekli Kaygı Düzeyleri ve Müsabaka Başarılarına Etkisi. Yüksek Lisans Tezi. Gazi Üniversitesi, Ankara.

Zeng, H. Z., Leung, R. W., \& Liu, W. (2008). An Examination Of Competitive Anxiety And Self-Confidence Among College Varsity Athletes, Journal Of Physical Education \& Recreation, 14(2), 6-12.

\section{Copyrights}

Copyright for this article is retained by the author(s), with first publication rights granted to the journal.

This is an open-access article distributed under the terms and conditions of the Creative Commons Attribution license which permits unrestricted use, distribution, and reproduction in any medium, provided the original work is properly cited. 